\title{
Characterization of Porous Magnesium Prepared by Powder Metallurgy - Influence of Pow- der Shape
}

Jaroslav Čapek, Dalibor Vojtěch

Faculty of Chemical Technology, Department of Metals and Corrosion Engineering, Institute of Chemical Technology, Technická 5, 16628 Prague 6, Czech Republic. E-mail: capekj@vscht.cz

Recently, demand for porous biodegradable load-bearing implants, called scaffolds, has been increasing. The interconnected porous structure allows transport of body fluids to healing tissue and ingrowth of new tissue into the implant. From the point of view of mechanical properties, magnesium based materials seem to be very promising for scaffold fabrication. Moreover, magnesium belongs to biodegradable and bioresorbable materials and magnesium ions support growth of bone tissue. In this study we prepared porous magnesium by powder metallurgy using ammonium bicarbonate as a space-holder material and focused on the influence of initial powder shape on sample microstructural, mechanical and corrosion characteristics. Based on obtained results we found out that the usage of spherical initial magnesium powder produced samples with more spherical pores in comparison with those of samples prepared from magnesium chips. Due to these microstructural differences samples prepared from spherical powder achieved higher values of mechanical characteristics.

Keywords: Powder metallurgy, porous magnesium, powder size influence.

\section{Acknowledgement}

The authors would like to thank to the Czech science foundation (project no. P108/12/G043).

\section{References}

[1] BOLIBRUCHOVÁ, D., BRŮNA, M. (2013). Influencing the crystallization of secondary alloy AlSi6Cu4 with strontium. In: Manufacturing Technology, Vol. 13, No. 1, pp. 7 - 14, Czech Republic.

[2] MICHALCOVÁ, A., VOJTĚCH, D. (2012). Structure of rapidly solidified aluminium alloys. In: Manufacturing Technology, Vol. 12, No. 13, pp. 166 - 169, Czech Republic.

[3] VOJTĚCH, D., KUBÁSEK, J., VODĚROVÁ, M. (2012). Structural, mechanical and in vitro corrosion characterization of as-cast magnesium based alloys for temporary biodegradable medical implants. In: Manufacturing Technology, Vol. 12 No. 13, pp. 285 - 292, Czech Republic.

[4] STAIGER, P. M., PIETAK, M. A., HUADMAI, J., DIAS, G. (2006). Magnesium and its alloys as orthopedic biomaterials: A review. In: Biomaterials, Vol. 27 No. 9, pp. 1728 - 1734, Nederland.

[5] ZHUANG, H., HAN, Y., FENG, A. (2008). Preparation, mechanical properties and in vitro biodegradation of porous magnesium scaffolds. In: Materials Science \& Engineering C, Vol. 28, No. 8, pp. 1462 - 1466, Nederland.

[6] ČAPEK, J., VOJTĚCH, D. (2013). Properties of porous magnesium prepared by powder metallurgy. In: Materials Science and Engineering: C, Vol. 33, No. 1, pp. 564 - 569, Nederland.

[7] WEN, C. E.; MABUCHI, M.; YAMADA, Y.; SHIMOJIMA, K., et al. (2001). In: Processing of biocompatible porous Ti and Mg. In: Scripta Materialia, Vol. 45, No. 10, pp. 1147 - 1153, Nederland.

[8] WEN, C. E., YAMADA, Y., SHIMOJIMA, K., CHINO, Y., et al. (2004). Compressibility of porous magnesium foam: dependency on porosity and pore size. In: Materials Letters, Vol. 58, No. 3-4, pp. 357 - 360, Nederland.

[9] YUSOP, A. H., BAKIR, A. A., SHAHAROM, N. A., ABDUL KADIR, M. R., et al. (2012). Porous Biodegradable Metals for Hard Tissue Scaffolds: A Review. In: International Journal of Biomaterials, Vol. 2012, 10 pages, USA.

[10] HAO, L. G., HAN, S. F., LI, D. W. (2009). Processing and mechanical properties of magnesium foams. In: Journal of porous materials, Vol. 16, No. 3, pp. $251-256$, USA.

[11] GU, X. N, ZHOU, W. R., ZHENG, Y. F., LIU, Y., LI, Y. X. (2010). Degradation and cytotoxicity of lotus-type porous pure magnesium as potential tissue engineering scaffold material. In: Materials Letters, Vol. 64, No. 17, pp. 1871 - 1874, Nederland.

[12] YUAN, L., YANXIANG, L., JIANG, W., HUAWEY, Z. (2005). Evaluation of porosity in lotus-type porous magnesium fabricated by metal/gas eutectic unidirectional solidification. In: Materials Science and Engineering: A, Vol. 402, No. 1-2, pp. $47-54$, Nederland. 